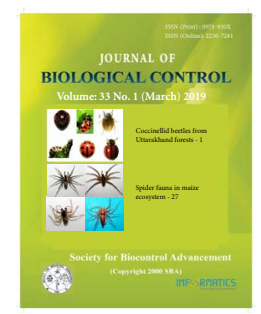

\title{
Diversity of predatory spider fauna in maize ecosystem
}

\author{
V. S. L. SARANYA ${ }^{1 *}$, K. SAMIAYYAN ${ }^{2}$ and M. SHANMUGA PREMA ${ }^{3}$ \\ ${ }^{1}$ AICRP on MAPB, Horticultural Research Station, Dr. Y.S.R. Horticultural University, Venkataramannagudem - 534101, \\ Andhra Pradesh, India \\ ${ }^{2}$ Mother Terasa College of Agriculture (Affliated to Tamil Nadu Agricultural University), Mettusalai, Illuppur (PO), \\ Pudukkottai - 622102, Tamil Nadu, India \\ ${ }^{3}$ Department of Agricultural Entomology, J.K.K. Muniraja College of Agriculture Science (Affliated to Tamil Nadu \\ Agricultural University), Gobichatipalayam, Erode - 638506, Tamil Nadu, India \\ ${ }^{*}$ Corresponding author E-mail: saranyavaranasi.agri@gmail.com
}

\begin{abstract}
Investigations conducted on the identification of predatory spider fauna in maize ecosystem throughout the crop growth, in Tamil Nadu Agricultural University, Coimbatore during 2013-2014 yielded around 2821 spiders, belonging to 16 species under 10 genera of 6 families from seedling to maturity stage. Majority of the spiders collected belonged to the families Lycosidae (1671 individuals), Salticidae (459 individuals), Oxyopidae (352 individuals), Gnaphosidae (178 individuals), Corinnidae (96 individuals) and Clubionidae (65 individuals). The predatory spider species dominating in the maize ecosystem included the species Lycosa barnesi, L. pseudoannulata, Pardosa birmanica, Salticus sp. and Hippasa lycosina. Dendrogram analysis of spiders revealed that the families, Clubionidae and Gnaphosidae were closely related when compared to other predatory spider families. Correlation analysis with the weather parameters showed that the predatory spider population had non-significant positive correlation with relative humidity at 14:22 hrs and negative correlation with all other weather parameters viz., maximum temperature, minimum temperature, relative humidity at 07:22 hrs, rainfall, sunshine hours and rainy days.
\end{abstract}

KEY WORDS: Diversity. maize crop ecosystem, spiders, predator.

(Article chronicle: Received: 12-10-2018; Revised: 16-02-2019; Accepted: 15-03-2019)

\section{INTRODUCTION:}

Spiders are among the most abundant predators of insects of terrestrial ecosystems (Darlene et al., 2003). They are ubiquitous, generalist super predators as well as specialized predators under different ecological niches (Marc and Canard, 1997). Because of their high abundance and predominantly insectivorous feeding habits, spiders are suspected to play an important predatory role in agroecosystems by lowering the insect densities, as well as stabilizing pest populations. The recent trends of chemical less agriculture i.e. reduced pesticide use and ecological sustainability have also led to increased interest in promoting the natural bio-control by conservation of the parasites and predators. In this context the spiders which are already present in all agro-ecosystems may have profound influence on the pests of crops. Considering the potential of these spiders as predators, their species distribution and diversity has been studied under the maize agro-ecosystem throughout the crop growth, in Eastern Block, Tamil Nadu Agricultural University, Coimbatore during 2013-2014.

\section{MATERIALS AND METHODS}

\section{Collection of spiders}

Sampling techniques employed for the collection of spiders included pitfall trapping, visual searching and hand picking methods. For placing the pitfall traps, plots were chosen at random in the field and a single trap was placed in each such plot. Around 20 traps were placed one each in 20 randomly selected plots in a field of nearly one acre area. The traps were set out using a plastic container $(15 \times 10 \mathrm{~cm})$ dug into the soil to the depth of $20 \mathrm{~cm}$. The traps were placed in the early morning. Teepol was used in the traps as a trapping fluid and it was changed weekly once. Observations were recorded at weekly intervals on the number and type of spiders trapped in each trap. Hand picking was done by walking diagonally in the field and care was taken to capture them without injuring. They were collected in polythene bags for further studies.

\section{Preservation and identification of spiders}

The method described by Tikader and Bal (1981) was followed for the preservation of the field collected 
spiders. Spiders collected from the pitfall traps were preserved in 70 per cent ethyl alcohol in glass vials of size $10 \mathrm{~cm} \times 2.5 \mathrm{~cm}$ and labeled. Spiders were relaxed and the body parts viz., legs, pedipalps, etc were adjusted as in the living form with the help of the needles and forceps. Spiders were then observed and photographed with a phase contrast microscope (LEICA DM 750) with a close up lens attachment to the camera with artificial illumination. The spiders were identified based on published literature and keys by comparing the morphological and taxonomical features (Tikader, 1987; Samiayyan, 2014).

\section{Diversity analysis of spiders in maize crop ecosystem}

Diversity indices are mathematical expressions that combine species richness and evenness as a measure of diversity and are frequently seen as indicators of a good ecosystem. Hence, different alpha diversity indices as well as similarity index were estimated to assess and compare the diversity and distribution of predatory spider fauna (at family, genus and species level) in maize crop ecosystem at different stages of the crop growth. The indices estimated are as follows:

\begin{tabular}{|c|c|c|}
\hline Species richness indices & Species dominance indices & Eveness index \\
\hline $\begin{array}{l}\text { Species number (Magurran, 1987) } \\
\text { Shannon's diversity index (Batten, 1976) }\end{array}$ & $\begin{array}{l}\text { Simpson's diversity index } \\
\text { (Simpson, 1949) }\end{array}$ & 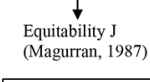 \\
\hline Fisher's alpha (Fisher et al., 1943) & Berger Parker diversity index & Similarity index \\
\hline Q. Statistic (Kempton and Taylor, 1976) & & \\
\hline Margalef's D (Clifford and Stephenson, 1975) & McIntosh index (McIntosh, 1967) & $\begin{array}{l}\text { Jaccard's similarity } \\
\text { coefficient (Jaccard, }\end{array}$ \\
\hline Brillouin diversity index (Magurran, 1987) & & 1908) \\
\hline
\end{tabular}

\section{Similarity index}

The binary data obtained by scoring the presence and absence of individual species and families in each of the crop stages of the maize ecosystem were subjected to cluster analysis. Cluster analysis starts with a matrix giving the similarity between each pair of families. The two most similar sites in this matrix are combined to form a single cluster. The analysis proceeds by successfully clustering similar sites until all are combined in a single dendrogram. However, these measures do not give any direct measure of beta diversity but might be used to infer the number of different communities present. It is also possible to identify the characteristic species in each community. Similarity matrix was constructed using Jaccard's similarity coefficient (Jaccard, 1908). The similarity values were used for cluster analysis. Sequential agglomerative hierarchical non-overlapping (SAHN) clustering was done using Unweighed Pair Group Method with Arithmetic Averages (UPGMA) method. Data analysis was done using NTSYSpc version 2.02 (Rolff, 1998).

\section{Influence of weather parameters on seasonal abundance of spiders}

Correlation between the weekly collection of spiders from the maize crop ecosystem and the weather parameters like maximum and minimum temperatures, relative humidity (morning and evening), rainfall and sunshine hours was also estimated to observe the influence of weather parameters on the seasonal incidence of spiders.

\section{RESULTS AND DISCUSSION}

\section{Collection and identification}

Studies on spider diversity in maize ecosystem yielded 16 species, 10 genera and 6 families of spiders. The vegetation architecture, intercultural operations and the weather conditions greatly influenced the collection of spiders in the maize ecosystem. In the overall collection of spiders (2821 individuals) throughout the crop growth period i.e. vegetative, flowering, grain filling and maturity stages, the highest number of spiders were recorded under the family Lycosidae (1671 individuals) followed by Salticidae (459 individuals), Oxyopidae (352 individuals), Gnaphosidae (178 individuals), Corinnidae (96 individuals) and Clubionidae (65 individuals) (Fig. 2). The spider collection included Clubiona sp., Oedignatha sp., Drassodes sp., Hippasa sp., Lycosa sp., Pardosa sp., Phidippus sp., Plexippus sp. and Salticus sp. Lycosidae was represented by Hippasa, Lycosa and Pardosa genera with majority of individuals from Lycosa and Pardosa genera. Among these Lycosa barnesi was the predominant species. Salticidae was represented by the genera Salticus, Plexippus and Phidippus, with majority of individuals from Salticus and Plexippus genera. Oxyopidae was represented by the species Oxyopes rufisternum and $O$. javanus. Gnaphosidae was represented by the genera Drassodes, Corinnidae by the genera Oedignatha and Clubionidae by the genera Clubiona (Fig.1).

The spider collection of the present study are in line with earlier reports of many workers (Singh and Sandhu, 1977; Jalali and Singh, 2002; Singh et al., 1975) who recorded several spider species of Araneidae, Lycosidae, Oxyopidae, Salticidae, Tetragnathidae and Clubionidae families from maize fields. Similarly, Andrea et al. (1999) reported that the wolf spiders (Lycosidae) are among the dominant epigeal predators of maize ecosystem. In a study by Patra et al. (2013) it was reported that about 13 spider species were recorded in maize ecosystems of Meghalaya and among the spider species recorded, Araneidae and Salticidae were found to be the most prominent species which is almost on par with the present findings. 


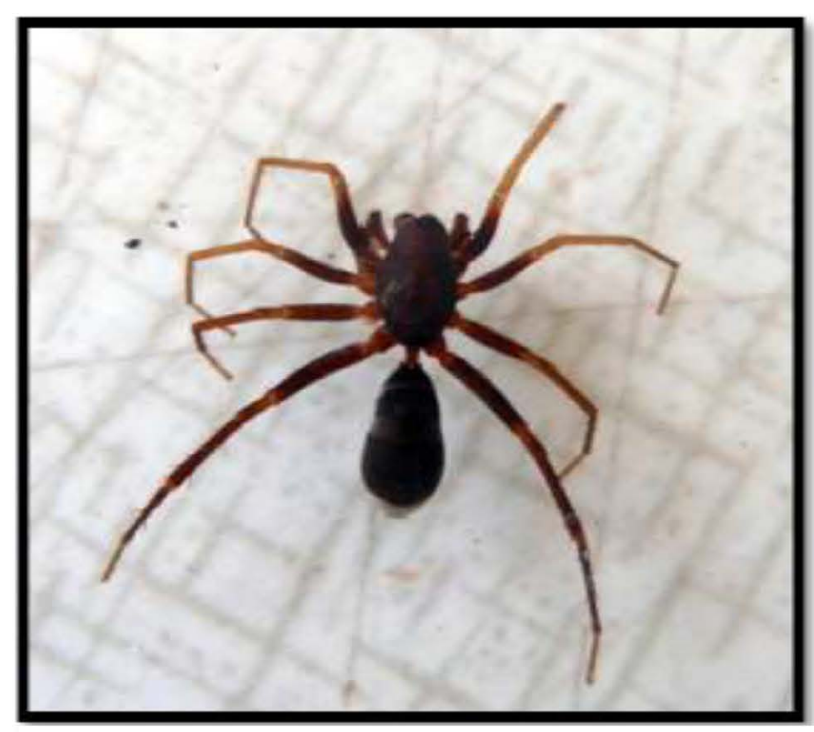

Oedignatha sp.

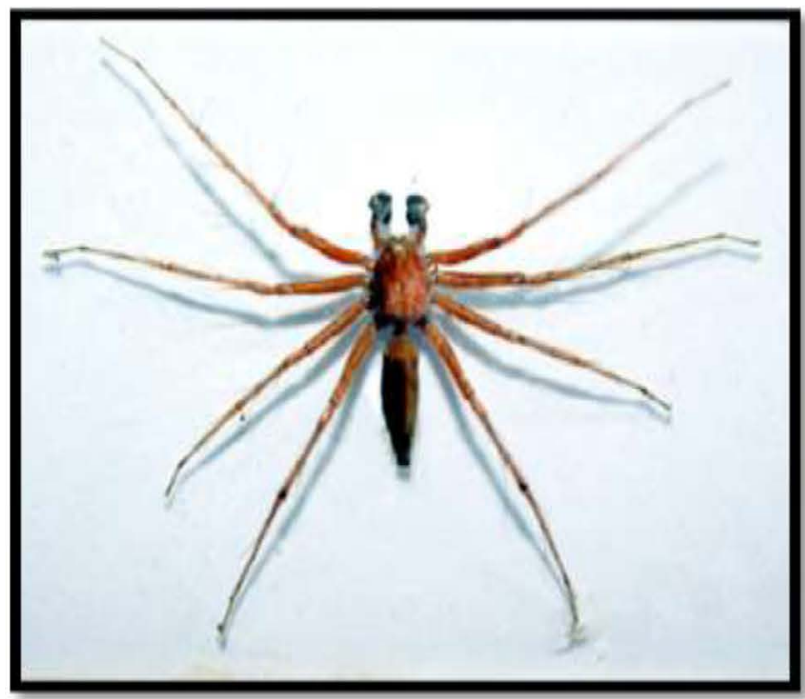

Oxypes rufisternum

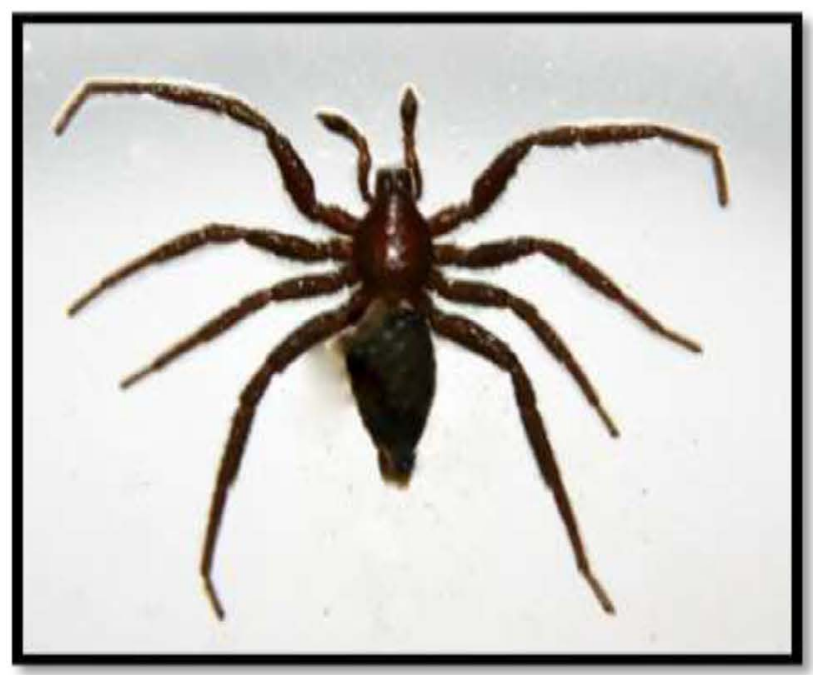

Drassodes sp.

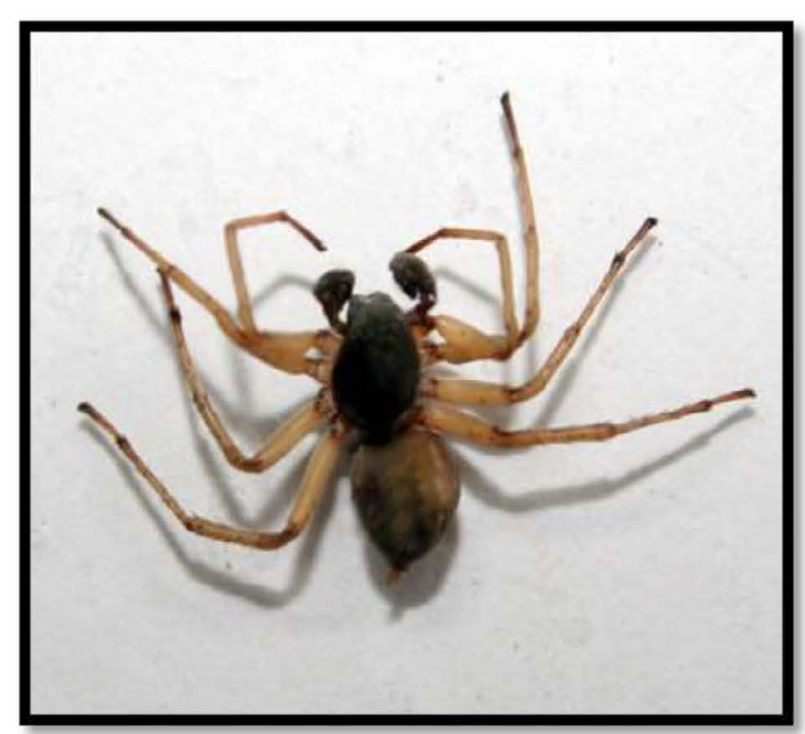

Clubiona sp.

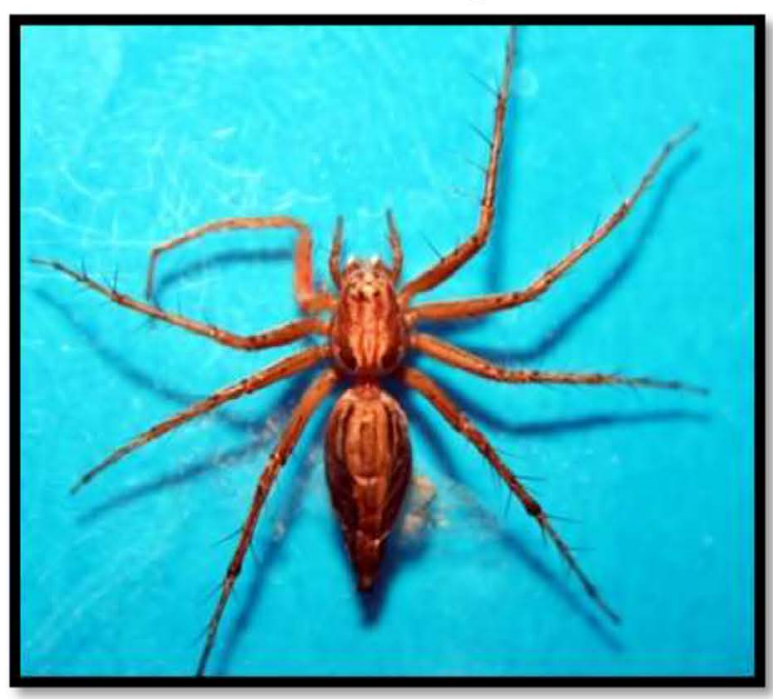

Oxypes javanus

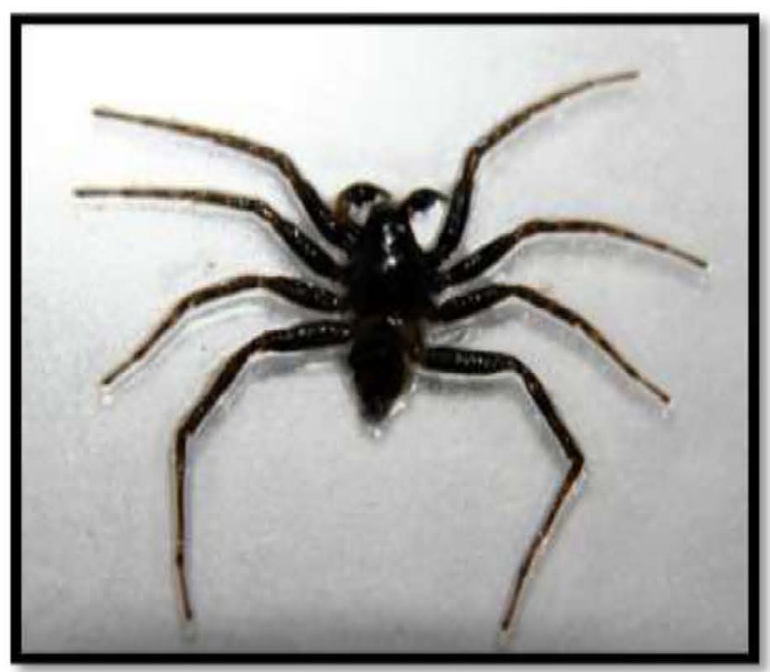

Drassodes sp. 


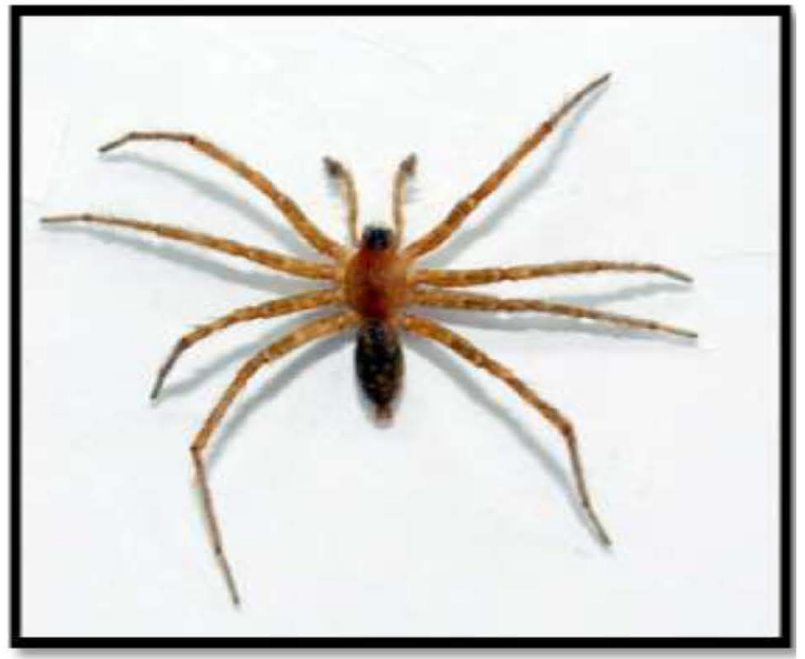

Hippasa lycosina

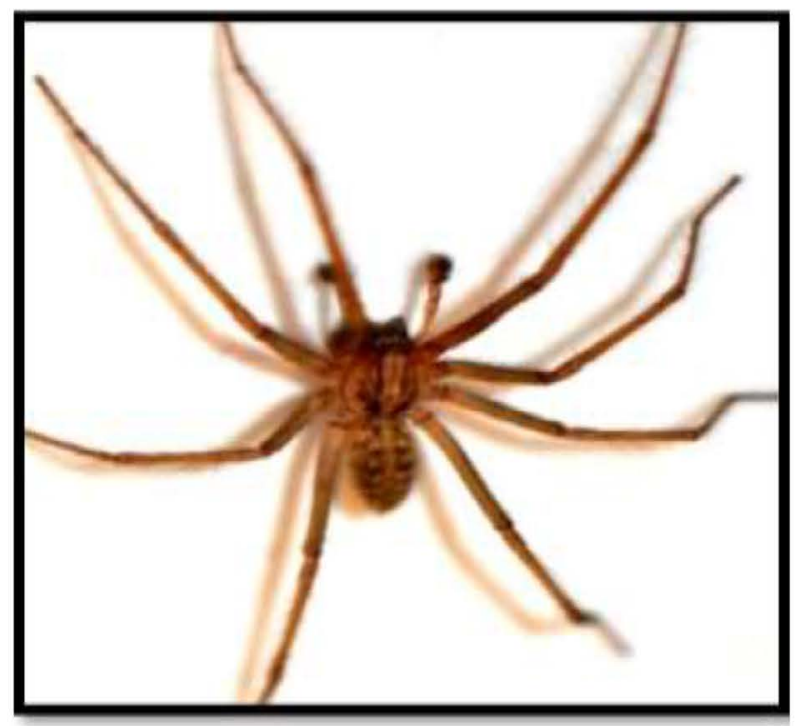

Pardosa sp. 2

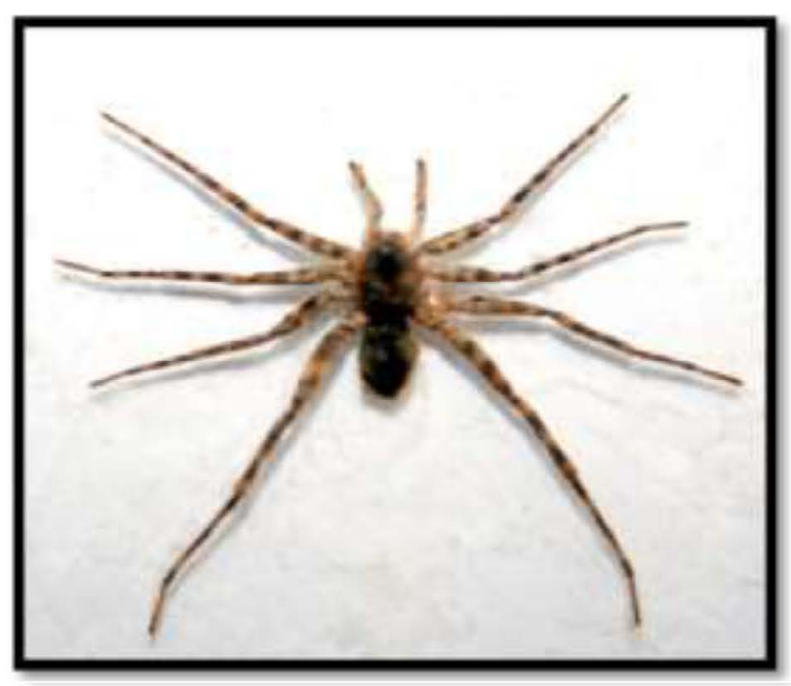

Pardosa sp. 3

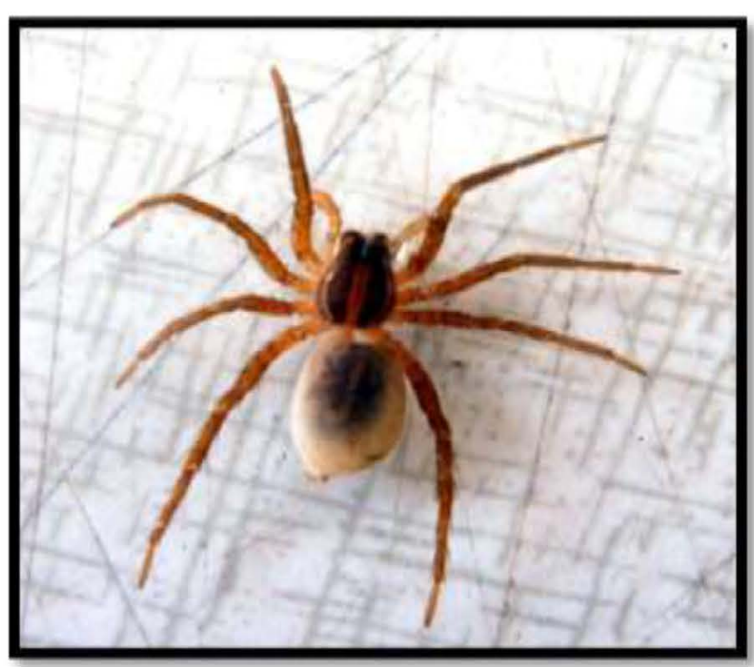

Lycosa barnesi

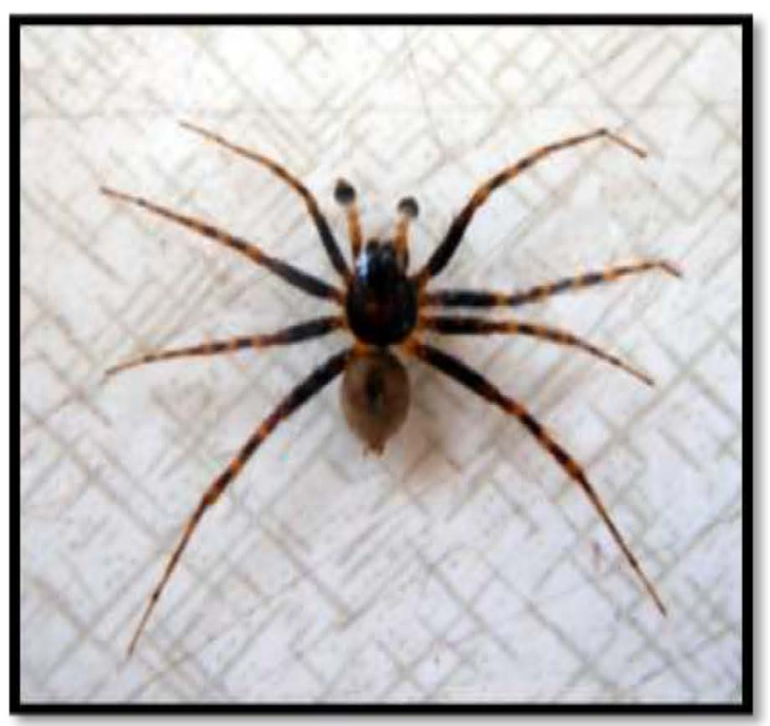

Pardosa birmanica

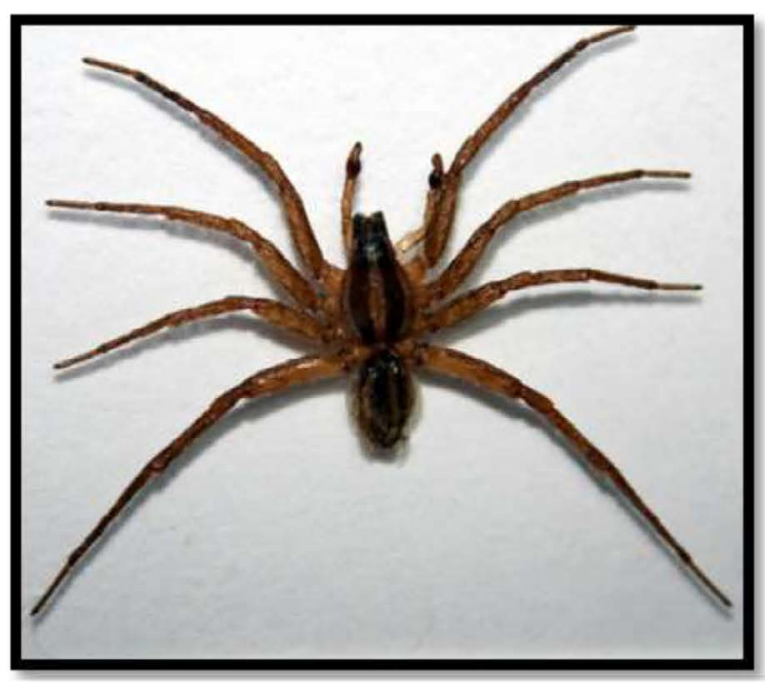

Lycosa pseudoannulata 


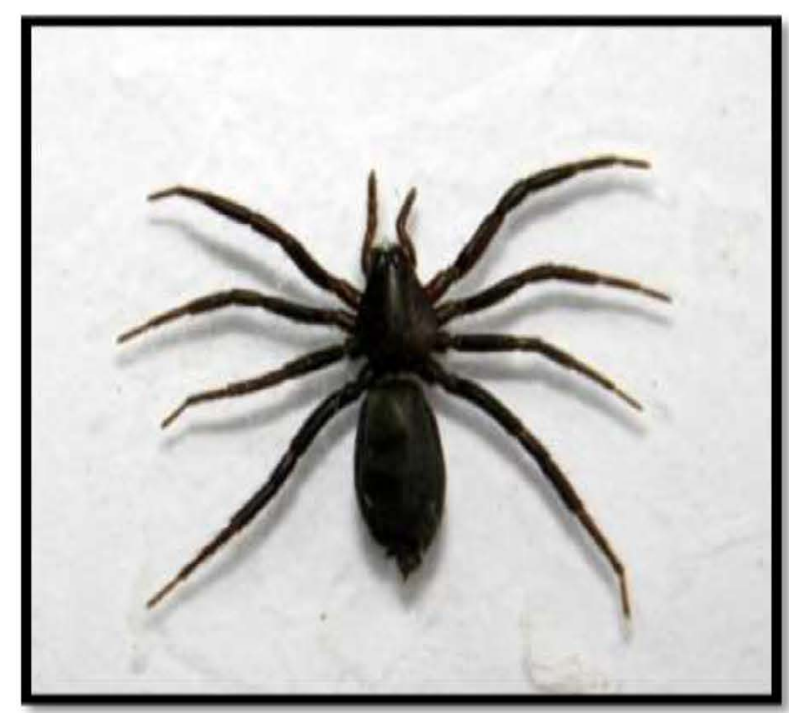

Salticus sp. (Female)

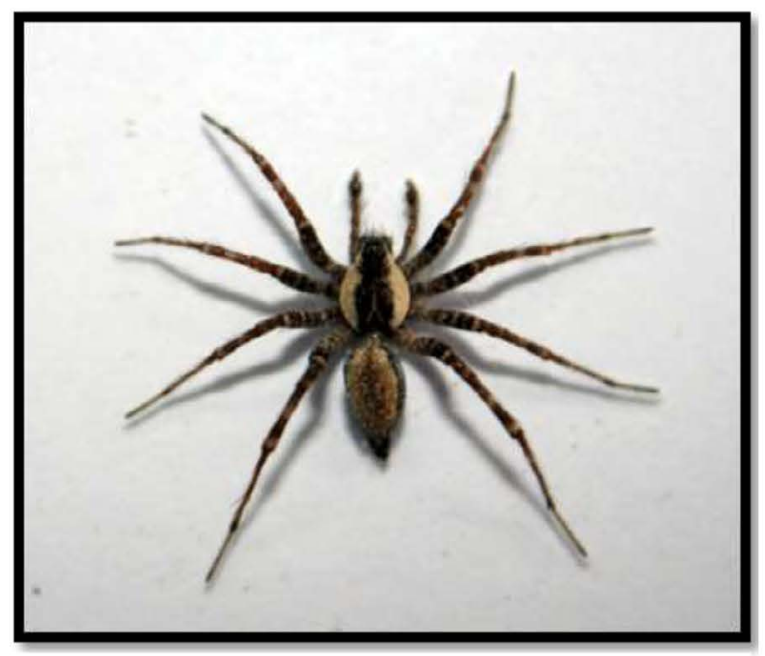

Plexippus sp. 1

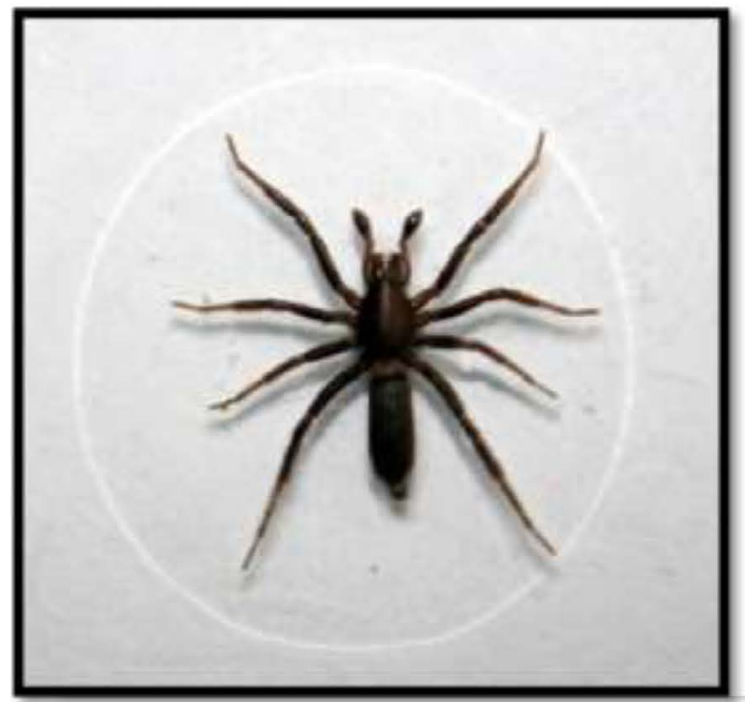

Salticus sp. (Male)

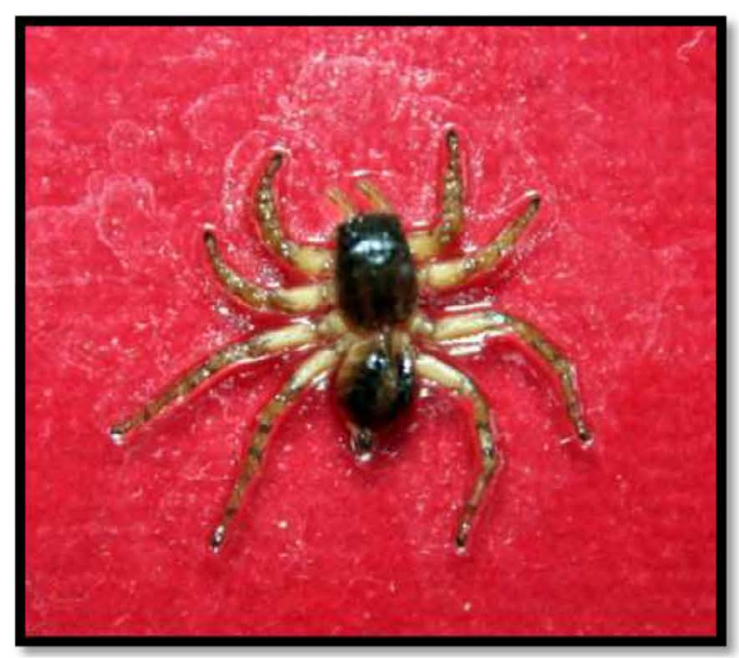

Phidippus sp.

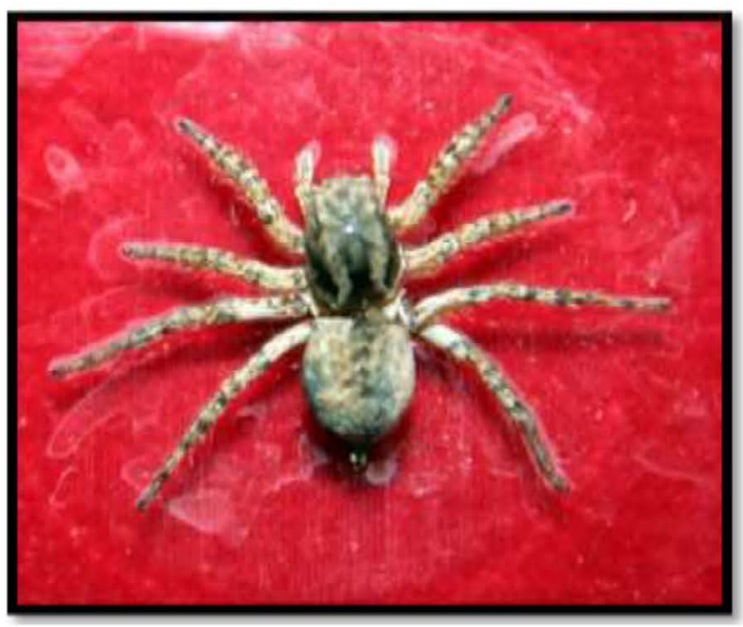

Plexippus sp. 2

Fig 1. Spiders collected from maize ecosystem 


\section{Diversity indices}

\section{Alpha diversity indices}

a. Species richness indices: In the present study, the highest species number (16.00) was observed in flowering (i.e. tasseling and silking stages) and grain filling stage, which coincide with the pest population. With reference to Fisher's Alpha, analysis at familial, generic and species

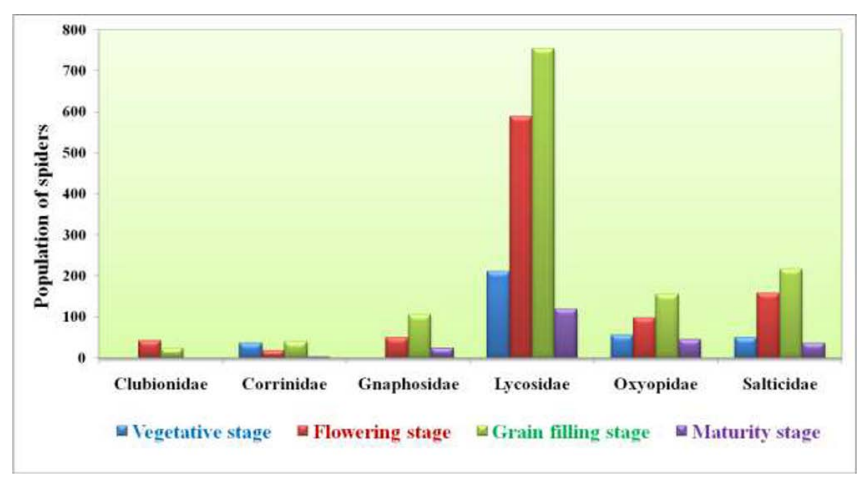

Fig 2. Abundance of predatory spider families at different stages of maize crop. level followed an identical pattern with the maximum diversity recorded during the maturity stage (5.7054) at species level. Analysis of species diversity using this index recorded a clearer picture of within habitat species diversity. Margalef's D index presented a similar picture at species level (3.0675) during the maturity stage. Brillouin index revealed that the spider diversity at species level was highest during the grain filling stage (2.5140). Shannon Weiner $\left(\mathrm{H}^{\prime}\right)$ index, the most widely used index by various ecologists revealed similar data, both at familial level and species level, with the highest value of index being recorded at the grain filling stage of the crop (2.5924) at the species level (Table 3).

Hughes (1978) concluded in his work that the taxonomic level of identification is one of the most important factors influencing the value of the ShannonWeiner index. In the current study, in most of the cases, estimating species richness or abundance based on family level was closer to species. Samways (2005) stated through his study that, while species surrogate measures are useful, there are risks involved with it, as the regional diversity might be overlooked. While the family richness

Table 1. Weather data recorded during the period of observation

\begin{tabular}{|c|c|c|c|c|c|c|c|c|}
\hline $\begin{array}{l}\text { Crop growth } \\
\text { period (weeks) }\end{array}$ & Spiders & Max. Temp. & Min. Temp. & RH (07:22) & RH (14:22) & Rainfall & $\begin{array}{c}\text { Sunshine } \\
\text { hours }\end{array}$ & Rainy days \\
\hline $1^{\mathrm{st}}$ & 46 & 30.1 & 18.3 & 87 & 37 & 0.0 & 8.8 & 0 \\
\hline $2^{\text {nd }}$ & 95 & 30.0 & 20.5 & 83 & 45 & 0.0 & 6.3 & 0 \\
\hline $3^{\text {rd }}$ & 118 & 30.8 & 20.9 & 81 & 46 & 0.0 & 7.3 & 0 \\
\hline $4^{\text {th }}$ & 91 & 29.9 & 19.9 & 84 & 41 & 0.0 & 7.9 & 0 \\
\hline $5^{\text {th }}$ & 308 & 30.8 & 19.1 & 82 & 39 & 0.0 & 9.2 & 0 \\
\hline $6^{\text {th }}$ & 299 & 33.2 & 16.9 & 71 & 26 & 0.0 & 10.2 & 0 \\
\hline $7^{\text {th }}$ & 321 & 33 & 21.5 & 81 & 44 & 0.0 & 8.2 & 0 \\
\hline $8^{\text {th }}$ & 356 & 31.8 & 22.4 & 81 & 47 & 0.2 & 5.0 & 0 \\
\hline $9^{\text {th }}$ & 330 & 32.8 & 22.8 & 81 & 47 & 0.0 & 6.7 & 0 \\
\hline $10^{\text {th }}$ & 329 & 32.6 & 23.2 & 80 & 46 & 0.0 & 6.3 & 0 \\
\hline $11^{\text {th }}$ & 277 & 34.2 & 20.5 & 73 & 26 & 0.0 & 9.9 & 0 \\
\hline $12^{\text {th }}$ & 83 & 36.3 & 23.3 & 72 & 30 & 0.0 & 10.1 & 0 \\
\hline $13^{\text {th }}$ & 54 & 36.2 & 21.4 & 70 & 26 & 0.0 & 9.9 & 0 \\
\hline $14^{\text {th }}$ & 50 & 36.7 & 25.1 & 76 & 37 & 0.0 & 9.3 & 0 \\
\hline $15^{\text {th }}$ & 28 & 35.9 & 24.2 & 83 & 41 & 17.4 & 6.8 & 1 \\
\hline $16^{\text {th }}$ & 9 & 35.9 & 24.2 & 84 & 38 & 0.0 & 8.6 & 0 \\
\hline
\end{tabular}


might be a good predictor of species richness, this approach has the inherent disadvantage of overlooking rare and threatened endemic species. Hoback et al. (1999) reported that ideally an estimate of diversity should examine organisms at species level, as any estimate of diversity at taxonomically higher level will be unable to explain the relationship between the species or population size. However, in the absence of taxonomic keys or expertise, the examination of the community for the purpose of estimating the diversity could be accomplished by use of family level identification.

b. Species dominance indices: Dominance measures are weighed towards the abundance of the commonest species rather than providing the measure of species richness. In the current study, only Simpson's index and Berger Parker index discriminated the variation at all the three levels i.e. familial, generic and species with the discrimination being more pronounced at the species level. Of the three indices, Simpson's index is commonly used for estimating diversity based on dominance with moderate discriminate ability according to Magurran (1987). McIntosh index recorded contradictory results as far as the three levels are considered, with similar trend being observed at all the levels (Table 3).

c. Evenness index: Equilitability $\mathrm{J}$ was used for the measure of evenness index in maize ecosystem in the present study. The index was similar in familial, generic and species level with a maximum value of index at grain filling stage of the crop (0.9493) and minimum value recorded at vegetative (0.5974) and maturity stages $(0.5147)$ at the species level (Table 3 ).

Similarity index: Dendrogram analysis of predatory spider families in maize crop, constructed based on the
Jaccard's coefficient depicted the similarity coefficient values ranging from 0.00 to 0.25 . The dendrogram separated the 6 families into 1 cluster based on 25 per cent similarity. The major cluster included the families, Clubionidae and Gnaphosidae with higher similarity coefficient (Fig. 3). Similarly, dendrogram of predatory spider species in maize crop was constructed. The similarity coefficient values ranged from 0.00 to 0.56 . The dendrogram separated the 16 species into 3 clusters based on 25 per cent similarity. The major clusters included the species Clubiona sp., Pardosa sp., Drassodes sp.1, Drassodes sp.2, Plexippus sp.1, Plexippus sp.2, Phidippus sp. and Hippasa lycosina with higher similarity coefficient when compared to the other species (Fig. 3).

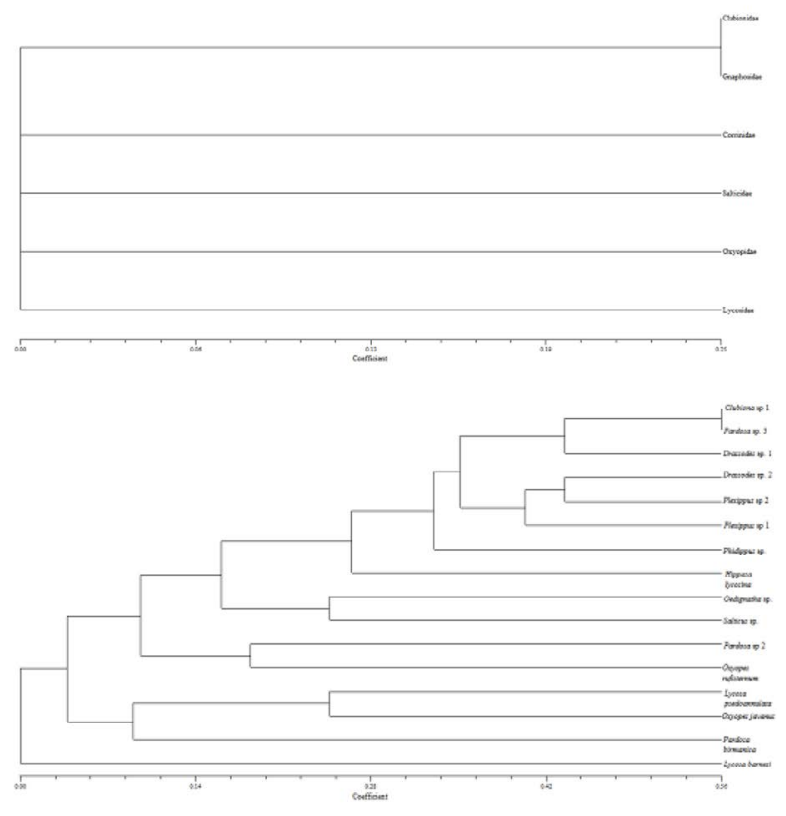

Fig. 3. Dendrograms showing the similarity of predatory spider families and species collected from maize ecosystem respectively based on Jaccard's similarity coefficient.

Table 2. Influence of weather parameters on seasonal abundance of spiders in maize ecosystem (Correlation analysis)

\begin{tabular}{|l|l|l|l|l|l|l|l|l|}
\hline \multicolumn{1}{|c|}{ Variables } & Spiders & $\begin{array}{c}\text { Max } \\
\text { temp }\end{array}$ & Min temp & $\begin{array}{c}\text { RH at } \\
07: 22 \mathrm{hrs}\end{array}$ & $\begin{array}{c}\text { RH } \\
\text { at } 14: 22 \mathrm{hrs}\end{array}$ & Rainfall & Sunshine & Rainy days \\
\hline Spiders & 1 & & & & & & & \\
\hline Max temp & -0.30746 & 1 & & & & & & \\
\hline Min temp & -0.25236 & 0.64257 & 1 & & & & & \\
\hline $\begin{array}{l}\text { RH } \\
\text { at } 07: 22 \text { hrs }\end{array}$ & -0.12264 & -0.57604 & 0.02591 & 1 & & & & \\
\hline $\begin{array}{l}\text { RH } \\
\text { at } 14: 22 \text { hrs }\end{array}$ & 0.21379 & -0.49453 & 0.28830 & 0.75376 & 1 & & & \\
\hline Rainfall & -0.28936 & 0.29737 & 0.31517 & 0.18934 & 0.09010 & 1 & & \\
\hline Sunshine & -0.24227 & 0.42090 & -0.28800 & -0.60313 & -0.88217 & -0.23147 & 1 & \\
\hline Rainy days & -0.29333 & 0.29883 & 0.31376 & 0.18821 & 0.08665 & 0.99993 & -0.22528 & 1 \\
\hline
\end{tabular}


Table 3. Spider diversity in maize ecosystem during 2013-2014 (Alpha diversity indices and Similarity index at species level)

\begin{tabular}{|c|c|c|c|c|c|c|c|c|c|c|c|}
\hline \multicolumn{2}{|c|}{$\begin{array}{c}\text { Crop growth } \\
\text { stages and Weeks }\end{array}$} & $\begin{array}{l}\text { Species } \\
\text { number }\end{array}$ & $\begin{array}{c}\text { Shannon } \\
\text {-Weiner } \\
\text { index) }\end{array}$ & $\begin{array}{c}\text { Fisher's } \\
\text { alpha } \\
\text { index }\end{array}$ & $\begin{array}{l}\text { Margalef's } \\
\text { D index }\end{array}$ & Q. statistic & $\begin{array}{l}\text { Brillouin } \\
\text { index }\end{array}$ & $\begin{array}{l}\text { Simp- } \\
\text { son's } \\
\text { index }\end{array}$ & $\begin{array}{l}\text { McIntosh } \\
\text { index }\end{array}$ & $\begin{array}{c}\text { Berger } \\
\text { Parker } \\
\text { index }\end{array}$ & $\begin{array}{l}\text { Equitabil- } \\
\text { ity J }\end{array}$ \\
\hline \multirow{4}{*}{$\begin{array}{l}\text { Vegetative } \\
\text { stage }\end{array}$} & $1^{\text {st }}$ & 7.00 & 1.6565 & 2.2982 & 1.5671 & 2.3270 & 1.4560 & 4.6833 & 0.6096 & 0.3695 & 0.5974 \\
\hline & $2^{\text {nd }}$ & 8.00 & 1.9049 & 2.0844 & 1.5372 & 3.7210 & 1.7632 & 6.0338 & 0.6488 & 0.2736 & 0.6870 \\
\hline & $3^{\text {rd }}$ & 8.00 & 1.8325 & 1.9417 & 1.4673 & 3.1059 & 1.7156 & 5.4786 & 0.6219 & 0.2881 & 0.6609 \\
\hline & $4^{\text {th }}$ & 8.00 & 1.8735 & 2.1156 & 1.5518 & 2.9070 & 1.7298 & 5.9348 & 0.6462 & 0.2747 & 0.6757 \\
\hline \multirow{3}{*}{$\begin{array}{l}\text { Flowering } \\
\text { stage }\end{array}$} & $5^{\text {th }}$ & 16.00 & 2.3795 & 3.5869 & 2.6178 & 5.2423 & 2.2779 & 8.2915 & 0.6878 & 0.2532 & 0.8582 \\
\hline & $6^{\text {th }}$ & 16.00 & 2.5240 & 3.6174 & 2.6314 & 7.9934 & 2.4160 & 10.448 & 0.7278 & 0.2107 & 0.9103 \\
\hline & $7^{\text {th }}$ & 16.00 & 2.5090 & 3.5452 & 2.5990 & 4.5591 & 2.4086 & 11.163 & 0.7371 & 0.1308 & 0.9049 \\
\hline \multirow{4}{*}{$\begin{array}{l}\text { Grain fill- } \\
\text { ing stage }\end{array}$} & $8^{\text {th }}$ & 16.00 & 2.5924 & 3.4456 & 2.5532 & 6.7475 & 2.4967 & 12.147 & 0.7482 & 0.1348 & 0.9350 \\
\hline & $9^{\text {th }}$ & 16.00 & 2.5194 & 3.5180 & 2.5866 & 6.0642 & 2.4193 & 10.625 & 0.7289 & 0.1666 & 0.9086 \\
\hline & $10^{\text {th }}$ & 16.00 & 2.5789 & 3.5209 & 2.5880 & 13.9150 & 2.4770 & 11.504 & 0.7413 & 0.1641 & 0.9301 \\
\hline & $11^{\text {th }}$ & 16.00 & 2.6320 & 3.6989 & 2.6671 & 9.0611 & 2.5140 & 12.892 & 0.7613 & 0.1407 & 0.9493 \\
\hline \multirow{5}{*}{$\begin{array}{l}\text { Maturity } \\
\text { stage }\end{array}$} & $12^{\text {th }}$ & 13.00 & 2.3410 & 4.3251 & 2.7156 & 5.6075 & 2.1082 & 10.009 & 0.7494 & 0.2048 & 0.8443 \\
\hline & $13^{\text {th }}$ & 11.00 & 2.2483 & 4.1760 & 2.5069 & 8.8093 & 1.9634 & 9.540 & 0.7542 & 0.2037 & 0.8108 \\
\hline & $14^{\text {th }}$ & 13.00 & 2.3030 & 5.7054 & 3.0675 & 5.4568 & 1.9725 & 9.5703 & 0.7572 & 0.2200 & 0.8306 \\
\hline & $15^{\text {th }}$ & 9.00 & 2.1072 & 4.5922 & 2.4008 & 6.4921 & 1.7277 & 10.216 & 0.7882 & 0.1785 & 0.7600 \\
\hline & $16^{\text {th }}$ & 5.00 & 1.4271 & 4.6325 & 1.8205 & 2.8854 & 0.9922 & 5.1429 & 0.7006 & 0.4444 & 0.5147 \\
\hline
\end{tabular}

\section{Influence of weather parameters on seasonal abundance of spiders in maize ecosystem}

In order to find out the effect of different abiotic factors on the occurrence of spiders, correlation was worked out and the results revealed that the occurrence of spiders in maize crop ecosystem was positively correlated with relative humidity at 14:22 hrs and negatively correlated with all the other weather parameters viz. maximum temperature, minimum temperature, relative humidity at 07:22 hrs, rainfall, sunshine hours and rainy days (Table 1 and 2). Extreme temperatures, both hot and cold, are the most extensively documented abiotic mortality factors for spiders. High temperatures have been shown to negatively affect spiders as thermal stress prevents the spiders from being active. Thus, the thermal environment limits foraging activities to certain periods of the day. However, the temperature influences different species in different ways and some spiders actually select warmer areas in order to enhance egg development e.g. some Lycosid species (Wise, 1993). According to a study conducted in Warangal, Telangana, the abundance of spider population showed positive correlation with relative humidity (morning and evening) and negative correlation with temperature and rainfall (Laxman et al., 2016). According to another study, the spider population showed positive correlation with temperature and relative humidity and negative correlation with rainfall, wind velocity and sunshine hours (Yogesh, 2017).

\section{ACKNOWLEDEMENTS}

The authors express sincere thanks to the Professor and Head, Department of Agricultural Entomology, Tamil Nadu Agricultural University, Coimbatore for providing the facilities to carry out the studies.

\section{REFERENCES}

Andrea A, Alda G. 2011. Spider fauna associated with wheat crops and adjacent habitats in Buenos Aires, Argentina. Rev Mex Biodivers. 82: 1176-1182.

Batten LA. 1976. Bird communities of some Killarney woodlands. Proc R Ir Acad. 76: 285-313.

Berger WH. and Parker FL. 1970. Diversity of planktonic foraminifera in deep sea sediments. Science 168: 1345-7. https://doi.org/10.1126/science.168.3937.1345

Clifford HT. and Stephenson W. 1975. An Introduction to Numerical Classification, Academic Press, London. pp. 229. https://doi.org/10.1016/B978-0-12-176750$1.50004-\mathrm{X}$

Darlene M, Drummond FA. and Alford R. 2003. Spider Predation in Agroecosystems: Can Spiders Effectively Control Pest Populations. Tech. Bullet., 190. Maine Agricultural and Forest Experiment Station, University of Maine, Orono, United states. pp. 5-28. 
Fisher RA, Corbet AS. and Williams CB. 1943. The relation between the number of species and the number of individuals in a random sample of an animal population. J Anim Ecol. 12: 42-58. https://doi.org/10.2307/1411

Hoback W, Tina M, Swados M, Stephenson M, Spomer P and Leon G. 1999. Trap colour and placement effect estimates of insect family level abundance and diversity in a Nebraska salt marsh. Entomol Exp Appl. 91: 393402. https://doi.org/10.1046/j.1570-7458.1999.00507.x

Hughes BD. 1978. The influence of factors other than pollution on the value of Shannon's diversity index for benthic macro-invertebrates in streams. Water Res. 12: 359-364. https://doi.org/10.1016/0043-1354(78)90124-0

Jaccard P. 1908. Nouvelles rescherches sur la distribution florale. Bull Soc Vaud Sci Nat. 44: 223-270.

Jalali SK. and Singh SP. 2002. Seasonal activity of stem borer and their natural enemies on fodder maize. Entomon 27: 137-146.

Kempton RA. and Taylor LR. 1976. Models and statistics for species diversity. Nature 262: 818-820. https://doi. org/10.1038/262818a0

Laxman, K. Kiranmai, U. Thirutathi and Ch. Sammaiah. 2016. Impact of weather factors on predatory spiders in $\mathrm{Bt}$ and non Bt-cotton fields of Warangal, Telangana. Biolife 4: 386-391.

Magurran AE. 1987. Ecological diversity and its measurement. Chapman and Hall, New York. pp.179. https://doi.org/10.1007/978-94-015-7358-0

Marc P. and Canard A. 1997. Maintaining spider biodiversity in agro ecosystems as a tool in pest control. Agric Ecosyst Environ. 62: 229-235. https://doi.org/10.1016/ S0167-8809(96)01133-4

McIntosh RP. 1967. An index of diversity and the relation of certain concepts to diversity. Ecology 48: 392-404. https://doi.org/10.2307/1932674

Patra S, Rahman Z, Bhumita P, Saikia K. and Azad Thakur NS. 2013. Study on pest complex and crop damage in maize in medium altitude hill of Meghalaya. Int J Life Sci. 8: 825-828.

Rolff J. 1998. NTSYSpc. 2.02i. Numerical taxonomy and multivariate analysis system, Appl. Biosystem Inc., New York. pp. 1-34.

Samiayyan, K. 2014. Spiders - The Generalist Super Predators in Agro-Ecosystems. Pp. 283-310. In: Dharam P (Ed.). Current Concepts and Ecological Perspective Elsevier Science Publisher. Amsterdam. Netherlands. https://doi. org/10.1016/B978-0-12-398529-3.00016-6

Samways MJ. 2005. Insect Diversity Conservation. Cambridge University Press. Cambridge. UK. 316p. https://doi.org/10.1017/CBO9780511614163

Simpson EH. 1949. Measurement of diversity. Nature C 163: 688.https://doi.org/10.1038/163688a0

Singh B, Dhaliwal JS, Battu GS. and Atwal AS. 1975. Population studies on the maize borer, Chilo partellus (Swinhoe) in the Punjab III. Role of parasitization by Apanteles flavipes (Cameron) in the population buildup. Indian J Ecol. 2: 115-124.

Singh G. and Sandhu GS. 1977. New records of predatory beetle on Chilo partellus (Swinhoe), a pest of maize. Curr Sci. 46: 422.

Tikader BK. 1987. Handbook of Indian Spiders. Navana Printing Works Pvt. Ltd. Zoological Survey of India, Calcutta. 180-231.

Tikader BK. and Bal A. 1981. Studies on some orb-weaving spiders of the genera Neoscona (Simon) and Araneus clerek of the family Araneidae (=Argiopidae). Rec Zool Surv India Occ Pap. 24: 1-60.

Wise DH. 1993. Spiders in Ecological Webs. Cambridge University Press, Cambridge, UK. 118-122. https://doi.org/10.1017/CBO9780511623431

Yogesh KS, Sonali D, Akash N, Rupesh, KG. and Manmohan SB. 2017. A study on seasonal distribution of spider fauna in maize field at Raipur, Chhattisgarh region. J Entomol Zool Studies 5: 1105-1108. 